\title{
Micro-environmental features associated to container-dwelling mosquitoes (Diptera: Culicidae) in an urban cemetery of the Dominican Republic
}

\author{
Mikel A. González , María Altagracia Rodríguez Sosa², Yohan Enmanuel Vásquez Bautista ${ }^{2}$, \\ Lorenzo Diéguez Fernández ${ }^{3}$, Miguel Borge de Prada ${ }^{2}$, Kelvin A. Guerrero² \\ \& Pedro María Alarcón-Elbal ${ }^{2 *}$ \\ 1. Departamento de Sanidad Animal, NEIKER- Instituto Vasco de Investigación y Desarrollo Agrario, Berreaga 1, 48160 \\ Derio, Bizkaia, Spain; mikel_alexander86@hotmail.com \\ 2. Laboratorio de Entomología, Universidad Agroforestal Fernando Arturo de Meriño (UAFAM), Jarabacoa, República \\ Dominicana; a.investigacion1@uafam.edu.do, a.investigacion2@uafam.edu.do,miguelborge90@gmail.com, \\ kaguerrero@hotmail.com, pedro.alarcon@uv.es \\ 3. Unidad Municipal de Higiene y Epidemiología (UMHE) de Camagüey, Cuba; lorenzodieguez95@gmail.com \\ * Correspondence
}

Received 02-V-2018. Corrected 01-X-2018. Accepted 21-I-2019.

\begin{abstract}
Mosquitoes (Diptera: Culicidae) are important vectors of diverse pathogenic organisms, particularly arboviruses and protozoa. The immature stages of mosquitoes occur in a wide range of natural or human-made aquatic habitats. On this basis, some anthropogenic places such as cemeteries, usually serve as thrive and productive artificial-breeding habitats for mosquitoes. Despite being important foci for vector species, urban cemeteries are frequently overlooked in control and surveillance programs. This study evaluates the association of ecological variables and attributes (type of material, presence of flowers, water availability and height from the ground) of the breeding sites with the levels of infestation of mosquito immature stages. In 2017, an entire urban cemetery in Jarabacoa (Dominican Republic) was sampled at two different climatic periods (March: dry and August: rainy) for the characterization of the artificial breeding-sites, collection of immature stages of culicids and subsequent laboratory rearing for species identification. In total 968 containers were studied, containing 7 758 immature stages in $203(21.0 \%)$ water-filled containers which accounted for four species: Culex quinquefasciatus (50.5\%), Aedes aegypti (47.1\%), Aedes albopictus (1.9\%) and Culex nigripalpus (0.4\%). The mean of $A$. aegypti immatures in infested containers was roughly two times higher compared to C. quinquefasciatus and significantly lower compared to A. albopictus. The total Container Index (CI) was $20.9 \%$, and among the type of materials, those made from rock (cement, ceramic, and mud) and plastic had the highest $\mathrm{CI}=25.9 \%$ and $23.4 \%$, respectively. Almost $95 \%$ of the total infested water-filled containers were made of plastic or rock. No association was found between the type of material of the containers and the density of mosquitoes. However, overall, greater densities of immature stages were found at ground than at higher levels. A weak positive correlation between water volume and density was found in some species of immature stages. Significantly higher number of $C$. quinquefasciatus were recorded in containers with flowers and large water volume. In contrast, A. aegypti immature stages were more frequent in containers without flowers. A weak negative association between water volume and infestations was found for A. albopictus immatures. As reflected of their opportunistic behaviour and broad ecological plasticity, Culex spp. and Aedes spp. mosquitoes were abundant pests in cemetery habitats where were able to breed in almost any kind of water-filled container regardless the type of
\end{abstract}

González, M. A., Rodríguez Sosa, M. A., Vásquez Bautista, Y. E., Diéguez Fernández, L., Borge de Prada, M., Guerrero, K. A., \& Alarcón-Elbal, P. M. (2019). Micro-environmental features associated to container-dwelling mosquitoes (Diptera: Culicidae) in an urban cemetery of the Dominican Republic. Revista de Biología Tropical, 67(1), 132-145. 
material. However, our study showed that some ecological variables have critical impact for the development of the immature stages of some species. The health authorities and cemetery keepers can benefit from these results by focusing on the implementation of detailed plans and integrated strategies for the control and prevention of cemetery infestations by mosquitoes.

Key words: Aedes; Culex; cemetery; artificial containers; environmental variables; Dominican Republic.

Over past years, several native and nonnative mosquito species are leading to novel epidemiological scenarios with high and dramatic transmission of infectious diseases such as yellow fever, dengue, chikungunya or Zika, among others (Medlock et al., 2012). The environmental changes caused by anthropic activities have a significant impact on the abundance and community composition of diverse species of mosquitoes (Ferraguti et al., 2016). For example, some mosquito species of the genera Aedes and Culex have been able to shift from natural larval habitats (e.g., fitotelmata and rock pools) to anthropic environments containing artificial containers. In urban settlements, artificial recipients (e.g., rain catch basins, discarded tires, tins, flower vases, and water storage containers) have become the most important breeding site for new invasive species such as Aedes albopictus (Skuse, 1894) (Bonizzoni, Gasperi, Chen, \& James, 2013) and for the widespread yellow fever mosquito Aedes aegypti (Linnaeus, 1762). Same kind of domestic containers also provide important larval habitat for synanthropic Culex mosquitoes (Subra, 1981).

Within these urbanised habitats, cemeteries offer high density spots with great proliferation of culicids (Vezzani \& Schweigmann, 2002). The reason is based on four basic requirements: energy supply (carbohydrates provided by funeral flowers), food (blood meal is provided by visitors and caretakers that are frequently around as well as by domestic and wild animals including dogs, cats, other small mammals, and birds), shelter (diverse vegetation types, ornamental vegetation and humancreated structures) and water-filled containers (artificial containers provided by visitors/local authorities, gravesites, mausoleums and natural sources such as tree holes and bromeliads)
(Vezzani, Velázquez, Soto, \& Schweigman, 2001; Vezzani, 2007).

Two additional factors contribute to complicate the picture. Cemeteries are frequently located in urban or periurban areas, often closely located to important human foci (e.g. residential areas, churches, hospitals, universities, and schools, among others), which increase the risk of transmission of mosquito-borne diseases to a high density of human populations. Secondly, cemeteries are neglected in standard and routine adult mosquito control campaigns by insecticide spraying, which potentially support vector population refugia (Abe, McCall, Lenhart, Villegas, \& Kroeger, 2005). These reasons make cemeteries as highly suitable habitats for several species of culicids adapted to urban human environments.

Although the interest on mosquito studies is rising, little updated information on this insect group is available in the Dominican Republic, with the exception of some studies published recently (Alarcón-Elbal et al., 2017; Rodríguez Sosa, Vásquez Bautista, Fimia-Duarte, Guerrero, \& Alarcón-Elbal, 2018; Rueda, Rodríguez Sosa, Vásquez Bautista, Guerrero, \& AlarcónElbal, 2018). First, because the characterization of mosquito breeding sites is limited. A better knowledge of these sites occupied by vector species would provide epidemiological information of paramount relevance. Cemetery surveys of immature mosquitoes are of great interest because these areas possess a variety of artificial-containers, which may be colonised by diverse species who have adapted to them. This is evidenced by almost 30 mosquito species found in cemeteries in the American continent including the invasive species $A$. aegypti and $A$. albopictus, and the urban Culex pipiens Linnaeus, 1758 and C. quinquefasciatus Say, 1823 as the most frequent ones (reviews Natal, 
Gonçalves, \& Taveira, 1997; Vezzani, 2007). Second, as features in breeding sites influence the development success of immature mosquito species, more studies evaluating the effects of multiple biotic and abiotic variables are needed. The selection of containers or survivorships of larvae/pupae in culicids, depends on different factors: water volume, container size, location, container colour, vegetation cover, water chemical characteristics, size of water surface, type of material, solar exposition, temperature, organic matter, detritus, microorganisms, and intra and interspecific competition, among others (Vezzani, 2007; Getachew et al., 2015; Rey \& Lounibos, 2015). Evaluating some of these micro-environmental variables in association with the different species and the occurrence of mosquito infestations levels are crucial for a better understanding of the mosquito vectors and essential for an efficient application of control methods.

In order to contribute to the knowledge of the mosquito community species and ecological factors involved on these important containerinhabiting mosquitoes, an urban cemetery in Jarabacoa (Dominican Republic) was studied. We examined the association between features of the containers (material of the container, presence of flowers, water availability, and height) and the levels of infestation of the immature stages of mosquitoes.

\section{MATERIALS AND METHODS}

Study area: The study was performed in Jarabacoa (La Vega Province, Dominican Republic), which has a population of ca. 32 600 inhabitants within an area of ca. $660 \mathrm{~km}^{2}$. Jarabacoa has a typical tropical rainforest climate with $1340 \mathrm{~mm}$ of annual rainfall, $22.9^{\circ} \mathrm{C}$ of annual daily mean temperature and Köppen climate classification: $A f$. The Municipal Cemetery of Jarabacoa (size $3535 \mathrm{~m}^{2}=0.35$ ha) is located just in the town centre (central point: $19^{\circ} 07^{\prime} 27.21^{\prime \prime} \mathrm{N} \& 70^{\circ} 38^{\prime} 33.39^{\prime \prime} \mathrm{W}$, 520 masl). The design and plant use is homogeneous along the cemetery, with sections separated by sidewalks and in general scarce vegetation structure. Reflecting the cultural practices, funeral and sympathy vases containing flowers was frequently provided by visitors in the cemetery during all the year.

Sampling, material processing and identification: Four working days were needed to examine and sample the entire cemetery. Two time periods were selected as representative of different climatic conditions, March 2017 (dry season, typically cooler, daily mean temperature (T) of $21.3^{\circ} \mathrm{C}$ and $112.3 \mathrm{~mm}$ of precipitations) and August 2017 (rainy season, typically warmer, daily mean T: $24.1{ }^{\circ} \mathrm{C}$ and $155.5 \mathrm{~mm}$ of precipitations).

All water filled containers (positive or negative) were counted and classified according to the type of material. Information about immature stages, water volume, presence of flowers inside the containers and height from the ground was recorded. All individuals of larvae and pupae in positive containers were collected with Pasteur pipettes on plastic trays. Then, immature stages of mosquitoes were transferred alive into mosquito breeders (Bioquip Products, USA) with their own water to be reared in the laboratory. The immature pupae were raised to adults so the species could be accurately identified. In general, the identification of immature stages was preferably carried out with IV instar larvae. Both adults and immature stages were identified using the key of González Broche (2006). Voucher specimens are deposited in the Laboratory of Entomology (UAFAM, Jarabacoa, Dominican Republic).

Due to the close resemblance of the type of containers, these were classified according to the material of which they are made of as follows: a) plastic, b) derived from sedimentary rocks (cement, ceramic, and mud), c) glass, d) metal (bronze, copper, and aluminium) and, e) others (bamboo, cardboard, granite, foam, and timber). The water volume of the container was measured by decanting into a graduated cylinder. The water volume filled in the containers was categorised into the following water levels: 0-100, 101-500, 501-1000 and > $1001 \mathrm{ml}$. The presence of flowers (or plants, hereafter 
as flowers) was recorded as positive (flowers inside the containers) or negative (no flowers). The height (position of the containers respect to the ground level) was categorised into the following heights scales: 0-50, 51-100, 101$150,>151 \mathrm{~cm}$.

Out of the 1207 potential artificial containers found, 239 (19.8\%) were excluded for further analysis due to logistic problems and/or inability to access, giving a total of 968 containers included in the study.

Statistical analysis: Non-parametric tests were performed after no-normality distribution was assumed. U-Mann-Whitney test was conducted to determine the influence of the presence of plants on the density of culicids. Kruskall-Wallis tests were performed to compare medians between immature stages inhabiting containers, to compare the density of culicids with the type of material and to compare the density with the height. The association between the water volume and the density of culicids was studied with the Spearman correlation coefficient. Mann-Whitney U comparison with Bonferroni correction was followed for multiple testing adjustment. The mean squares of each season (monthly variation) was analysed by F-statistic. The occurrence of immature stages (larvae and pupae) for both trapping periods in the cemetery was represented by Least Square Means (LS Means) based on a linear model (ANOVA).

All statistical tests focused on the three most common species identified (A. aegypti, $A$. albopictus, and $C$. quinquefasciatus), the total larvae of these species, total pupae of these species, and the total Culicidae including the larvae and pupae of these studied species. Data is expressed for both trapping periods pooled, otherwise is specified. Container indices for the material types were compared using the chisquared test (difference between proportions).

The Container Index $(\mathrm{CI})=$ (positive containers infested/number of inspected containers $x$ 100) was calculated for the total immature stages and for each type of material (Webb, 2008). The total density of the containers in the cemetery was calculated as the total number of containers (including those inaccessible)/area of the cemetery.

The significance level was set to alpha $=$ 0.05 . All statistical tests were conducted using IBM SPSS V22.O software (IBM, 2016). Graphs were made using Microsoft Excel.

\section{RESULTS}

In total 968 containers were studied for both trapping periods (483 in March and 485 in August) with a density of 3.48 per ha. Out of 968 containers, $677(69.9 \%)$ contained water, of which 203 (21.0\% of the total) were positive for immature mosquitoes (117 and 86 in March and August, respectively).

Abundance: In total 7758 immature stages $(97.9 \%$ of the total catches) found in water-filled containers were accurately identified to four species of culicids. Up to 7141 specimens $(90.5 \%)$ were recorded as larvae and the remaining as pupae. C. quinquefasciatus and $A$. aegypti accounted for $50.5 \%$, and $47.1 \%$, respectively, while A. albopictus and C. nigripalpus Theobald, 1901 represented less than $2.5 \%$ of the total catches (Table 1). Of the 203 containers with immature mosquitoes, A. aegypti was found in 158 containers (77.8 $\%)$, C. quinquefasciatus in 76 containers (37.4 $\%)$, A. albopictus in 30 containers (14.7\%) and $C$. nigripalpus in 4 (1.9\%). The mean of A. albopictus immatures (Mean, $\mathrm{M} \pm$ Standard Deviation, $\mathrm{SD}=5.0 \pm 3.1$ ) per inhabited container was significantly inferior (Kruskall-Wallis $=6.4 ; \mathrm{P}=0.007)$ compared to A. aegypti $(23.1$ $\pm 8.5)$ and $C$. quinquefasciatus $(51.6 \pm 12.1)$.

Monthly variation: Significantly more specimens were collected in March than in August $(\mathrm{F}=3.723$; $\mathrm{P}=0.006)$. When comparing the abundance between both periods, $A$. aegypti was the predominant species during March whereas C. quinquefasciatus dominated in the warmer sampling period. The abundance of A. albopictus increased from March to 
TABLE 1

Immature stages of Culicidae recorded for both trapping periods in the cemetery of Jarabacoa, Dominican Republic

\begin{tabular}{lcccc}
\multicolumn{1}{c}{ Species } & March & August & \multicolumn{2}{c}{ Both periods } \\
C. quinquefasciatus & 1824 & 2097 & 3921 & $(50.5 \%)$ \\
A. aegypti & 2599 & 1058 & 3657 & $(47.1 \%)$ \\
A. albopictus & 34 & 117 & 151 & $(1.9 \%)$ \\
C. nigripalpus & 0 & 29 & 29 & $(0.4 \%)$ \\
Total culicids & 4457 & 3301 & 7758 & \\
\hline
\end{tabular}

August. C. nigripalpus was recorded only in August (Table 1; Fig. 1).

Water volume: In total, 853 (476 and 377 for March and August, respectively) out of 968 were water-filled containers. The water volume ranged from 10 to $10000 \mathrm{~cm}^{3}(\mathrm{M} \pm$ $\mathrm{SD}=735.5 \pm 632 \mathrm{~cm}^{3}$ ). No correlation was found between water volume and density of immature stages in $A$. aegypti (Spearman test $\mathrm{r}=0.122 ; \mathrm{P}=0.144)$, total larvae $(\mathrm{r}=0.166$; $\mathrm{P}=0.066)$, total pupae $(\mathrm{r}=0.149 ; \mathrm{P}=0.198)$. In contrast, a weak positive correlation was found in $C$. quinquefasciatus $(\mathrm{r}=0.302 ; \mathrm{P}=$ $0.007)$ and total culicids $(\mathrm{r}=0.330 ; \mathrm{P}=0.006)$. Overall, a greater proportion of immature stages was recorded for 101-1 $000 \mathrm{ml}$, in contrast to $\leq 100 \mathrm{ml}$ containers, which supported the lowest infestations, e.g., C. quinquefasciatus (Average Range, $\mathrm{AR}=63.5 \mathrm{in}>101 \mathrm{ml}$ and $\mathrm{AR}=115.1 \mathrm{in}>1001 \mathrm{ml}$ ) and in total culicids $(\mathrm{AR}=85.9$ in $>101 \mathrm{ml}$ and $\mathrm{AR}=111.1$ in $>1001 \mathrm{ml}$ ). A weak negative correlation was found in A. albopictus immatures $(\mathrm{r}=-0.314$; $\mathrm{P}=0.007$ ) showing the occurrence of the lowest infestations in water-filled containers with $>1001 \mathrm{ml}$ compared to the other ranges. The mean height of the containers for each type of material can be consulted in Table 2 .

Presence of flowers: In total, 114 (56.7 \%), 56 and 58 containers in March and August respectively, had flowers. Significantly higher number of total culicids were recorded in

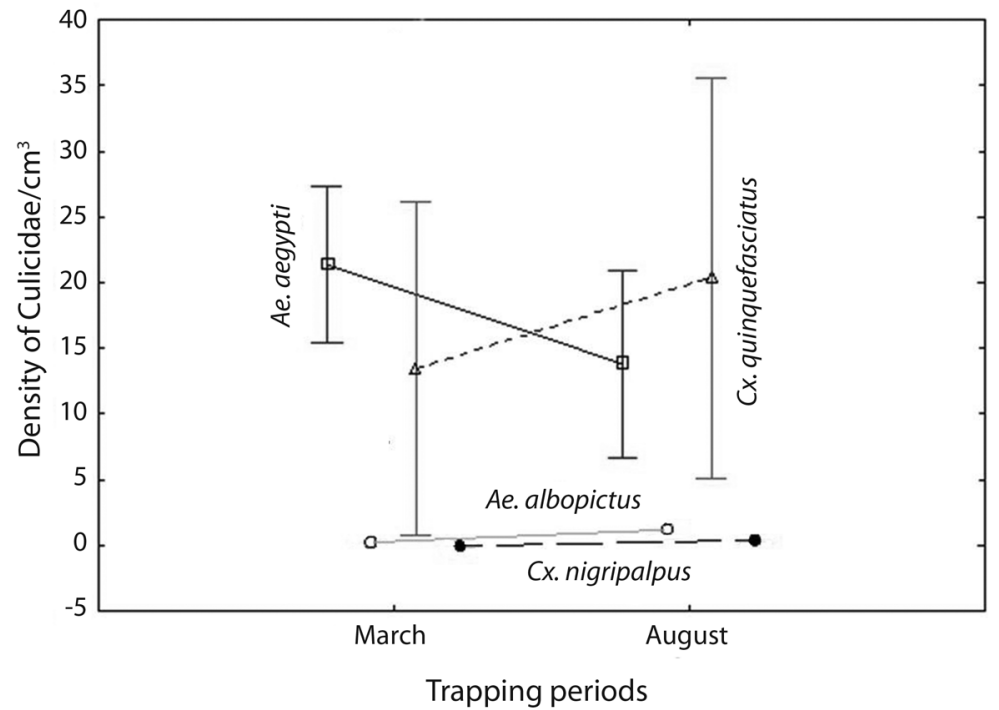

Fig. 1. Ocurrence of immature stages (larvae and pupae) for both trapping periods in the cemetery of Jarabacoa, Dominican Republic (represented by LS means and vertical bars denote 0.95 confidence intervals). 
TABLE 2

Characteristics of immature culicids recorded for both trapping periods (pooled) in the cemetery of Jarabacoa, Dominican Republic

\begin{tabular}{lcccccc}
\multicolumn{1}{c}{ Material $^{1}$} & $\mathrm{H}(\mathrm{cm})$ & WV $\left(\mathrm{cm}^{3}\right)$ & WFC & Flower & CI & $\mathrm{n}^{\text {o }}$ specimens \\
Plastic & 69.6 & 784.6 & 372 & 72 & 23.4 & 4956 \\
Rock & 65.9 & 636.8 & 134 & 36 & 25.9 & 2412 \\
Glass & 105.4 & 95.8 & 70 & 2 & 3.8 & 178 \\
Metal & 6.25 & 346.8 & 21 & 2 & 12.9 & 119 \\
Other & 0.0 & 2037.5 & 6 & 2 & 2.0 & 93 \\
\hline
\end{tabular}

$\mathrm{H}=$ Mean height; WV = Mean water volume; WFC = Water-filled containers; Flower: Containers with water and flowers; $\mathrm{CI}=$ Container Index $(\%) .{ }^{1}$ Rock (cement, ceramic and, mud), metal (bronze, copper and, aluminium), and other (bamboo, cardboard, granite, foam and timber).

flower pots containing plants (Mann-Whitney $\mathrm{U}$ test $=3$ 953.5; $\mathrm{P}=0.008)$. This difference was significant either for total larvae (U test $=$ 4 059.5; $\mathrm{P}=0.016)$ or total pupae $(\mathrm{U}=4275.5$; $\mathrm{P}=0.042$ ). Among the four species, the density of immature stages of $C$. quinquefasciatus was greater in presence of flowers $(\mathrm{U}=3531.0 ; \mathrm{P}=$ 0.000 ). In contrast, containers without flowers were favourable to $A$. aegypti immature stages $(\mathrm{U}=4257 ; \mathrm{P}=0.049)$. The number of containers for each type of materials can be consulted in Table 2.

Type of material and distribution: Out of 203 positive containers, $62.1 \%$ (126) were plastic material, $32.5 \%$ (66) were derived from sedimentary rocks, $2.4 \%$ (5) from glass,
$1.9 \%$ (4) from metal and $0.9 \%$ (2) from other materials. Out of 7758 immature mosquitoes collected from the positive containers, 4957 (64\%) were retrieved from plastic containers, 2412 (31\%) from sedimentary rocks, 178 (2.3 $\%)$ from glass, $119(1.5 \%)$ from metal and 93 (1.2\%) from other diverse materials (Fig. 2). The number of specimens was three times greater in plastic containers that in rock containers in March, but similar numbers were observed in August (Fig. 2).

Container Index (CI): March resulted in a $\mathrm{CI}=23.07 \%$ and August in $\mathrm{CI}=18.7$ $\%$. Within type of material, plastic containers had a $\mathrm{CI}=23.4 \%$, materials derived from $\operatorname{rock}(\mathrm{CI}=25.9 \%)$, metal $(\mathrm{CI}=12.9 \%)$, and

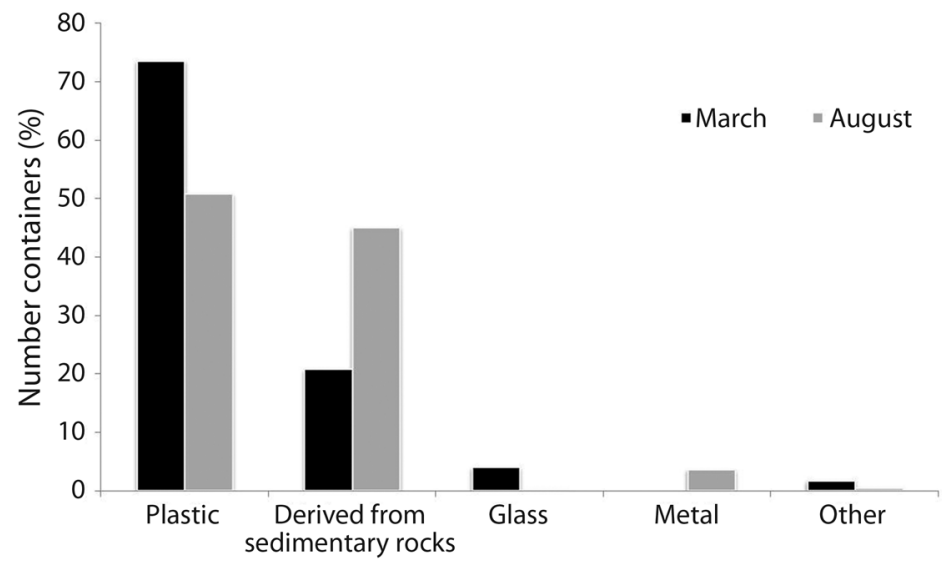

Type of material

Fig. 2. Distribution of immature stages (larvae and pupae) according to the type of material for both trapping periods in the cemetery of Jarabacoa, Dominican Republic. 


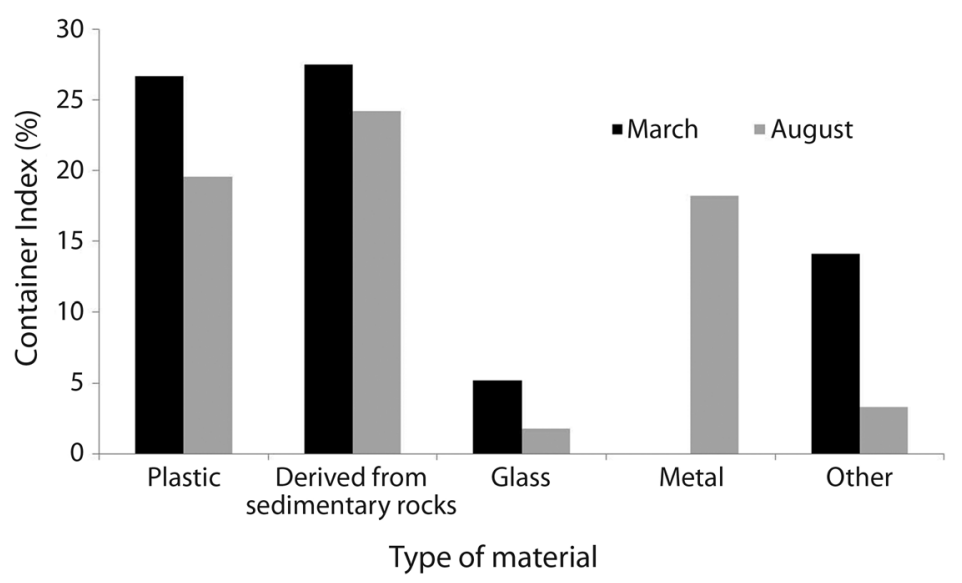

Fig. 3. Container Index according to the type of material for both sampling periods in the cemetery of Jarabacoa, Dominican Republic.

other materials including glass $(\mathrm{CI}=5.8 \%)$ (Table 2, Fig. 3). The CI between March and August for plastic and derived from rocks were not statistically different (Kruskall-Wallis $\chi^{2}=$ 12.4 and 16.1 , respectively; d.f. $=1 ; \mathrm{P} \geq 0.05$ ) but varied significantly between both trapping periods for glass, metal and other materials (all $\mathrm{P} \geq 0.05$; Fig. 3).

Height from the ground: Height of containers ranged from 0 to $300 \mathrm{~cm}(\mathrm{M} \pm \mathrm{SD}=$ $67.9 \pm 68.3 \mathrm{~cm})$. No correlation was found between the height and the density of total larvae (Spearman test $\mathrm{r}=-0.135 ; \mathrm{P}=0.055$ ), total pupae $(\mathrm{r}=-0.013 ; \mathrm{P}=0.858)$ and total culicids $(\mathrm{r}=-0.125 ; \mathrm{P}=0.075)$. However, statistical differences in total culicids were found when Kruskal-Wallis test was performed $\left(\chi^{2}=14.0\right.$, $\mathrm{P}=0.016)$ and greater densities of vectors were found at ground level $(0 \mathrm{~cm}$ than from 50 to $>151 \mathrm{~cm})$. The mean height of the containers for each type of material can be consulted in Table 2 .

\section{DISCUSSION}

This study highlights the importance of cemeteries as foci with high density of vector species. In previous works, the roles of cemeteries have been reported as potential breeding sites not only for dengue and chikungunya vector species like $A$. aegypti and A. albopictus but also for other species. Infected Aedes triseriatus (Say, 1832) with La Crosse encephalitis arbovirus were collected in cemeteries and consequently, these could serve as an ideal bridge to spread vector populations and virus amplification between rural native sites and urban environments (Trout Fryxell et al., 2015). The cemetery in this study supported breeding environment in the urban centre of Jarabacoa. In $500 \mathrm{~m}$ radius, there is a City Hall and diverse buildings with intense movement of people such as two bus stations, various entertainment venues, cultural centres, a hospital, a police department and a gas station, thus increasing the risk of arbovirus transmission to the population (Abe et al., 2005). Considering that the dispersal of Aedes and Culex adult mosquitoes could reach several hundred meters, it is likely that this cemetery serve as one of the most important sources of mosquitoes for the municipality of Jarabacoa.

The four species found in our survey have been incriminated in the transmission of diseases to humans worldwide. The role of both aedine species as vectors, particularly $A$. aegypti, was evidenced after the epidemics of dengue and chikungunya in the Caribbean region and subsequently corroborated by the 
detection of field-collected A. aegypti infected with both viruses in Martinique (Service, 2012; Farraudière et al., 2017). Aedes albopictus has been reported as a vector of dengue in American countries such as Brazil (de Figueiredo et al., 2010) and Mexico (Ibáñez-Bernal et al., 1997), and showed to be a competent vector of chikungunya (Vazeille et al., 2007). Regarding chikungunya arbovirus, recent studies carried out in the Dominican Republic, Martinique and Guadeloupe suggest that deaths caused by this virus are not as rare as had been suggested previously (Freitas, Alarcón-Elbal, Paulino-Ramirez, \& Donalisio, 2018; Freitas, Alarcón-Elbal, \& Donalisio, 2018). The presence of the Southern house mosquito $C$. quinquefasciatus should not be neglected, as it likely plays an important role in maintaining viruses within bird populations and is responsible for transmitting the filarial nematode Wuchereria bancrofti, which is still endemic in the Hispaniola (Addiss \& Chuke, 2002). Culex nigripalpus is involved in the transmission of Venezuelan equine encephalitis virus (Mendéz et al., 2001), St. Louis encephalitis virus (Day, Curtis, \& Edman, 1990) and West Nile virus (Turell et al., 2005).

The presence of $A$. aegypti, A. albopictus, and $C$. quinquefasciatus into a lesser extent, have been well-documented in cemeteries worldwide (reviewed in Vezzani, 2007). However, only two reports for C. nigripalpus in Venezuela (Barrera, Machado-Alison, \& Bulla, 1979) and Florida (Leisnham, LaDeau, \& Juliano, 2014) exist. Regarding monthly variation, the dry season was a little more productive in immature stages of culicids than the wet season. We found some differences in the abundance of vectors between both sampling periods. Aedes aegypti abundances were clearly superior to its conspecific $A$. albopictus in both study periods. This contrasts, the fact that A. albopictus is a more recent invasive species with interspecific competitive superiority characteristics. The differences in the abundance between $A$. aegypti and $C$. quinquefasciatus between both sampling periods might respond to rainfall patterns (Leisnham et al., 2014), although data seems insufficient to establish conclusions. This is not unusual as tropical areas have continuous periods of raining and mosquito fauna proliferates all year around. Although mosquitoes are more abundant during the wet season (Barrera, MachadoAlison, \& Bulla, 1979; Shultz, 1989; 1993), the availability of artificial breeding containers in cemeteries is ensured both by the water-filled vases provided by humans and rains along the whole year, including the dry season. In particular, changes in mosquito's density might be reinforced to special commemorative dates where new flowerpots are placed (Barrera et al., 1982; Gonçalves, 1989; Natal et al., 1997). As noted by Vezzani and Albicócco (2009), there was no clear correlation between precipitation indicated and CI values.

The number of immatures per inhabited breeding site varied between species. Aedes aegypti and $C$. quinquefasciatus, the dominant species breeding in artificial containers in the study, coexisted although the latter was found in lower numbers. The number of $A$. aegypti immatures per infested container were slightly higher compared to previous reports (Vezzani \& Schweigmann, 2002; Abe et al., 2005). A lower mean number of $A$. albopictus per infested conspecific container was reported here. Whether these differences in the numbers are related to interspecific interactions, food competence or distinct oviposition patterns and/or subsequent success in the survival of immature are not yet fully understood but might be considered as possible explanations (Vezzani \& Albicócco, 2009).

In relation to the micro-environmental features associated with breeding mosquitoes, the water volume content had an influence in the infestation levels of A. aegypti and C. quinquefasciatus. In this respect, it seems that higher numbers are record in larger vases than lower ones in accordance to other published works in cemeteries (Vezzani, Velásquez, \& Schweigmann, 2004; Abe et al., 2005). As opposed to our study, the latter did not found immature stages of $A$. aegypti in containers with less than $100 \mathrm{ml}$ of water. The opposite pattern was 
observed for A. albopictus, possibly responding to their natural tendency of laying eggs in smaller volumes of water under natural conditions. Flower vases usually store lower water volume in comparison with other studies with access to multiple-sized containers.

Vases with flowers provide a variable habitat, which can be used by different mosquito species as organic matter gains importance. For example, Aedes spp. are typically found when water is clean, and later as water becomes more organic due to flowers, Culex spp. becomes predominant (Barrera et al., 1979; 1981; Natal et al., 1997; Vezzani et al., 2001; Vezzani et al., 2004; Abe et al., 2005; Vezzani, 2007). Our study documented that $C$. quinquefasciatus densities were higher in containers with flowers, which presumably have higher organic matter in the water. In contrast, immature A. aegypti density was greater in absence of flowers, which is in line with the results reported by Abe et al. (2005).

Our results failed to show an association between type of material and infestation for the species studied. This is not surprising due to the high opportunistic behaviour and ecological plasticity showed by A. aegypti and A. albopictus which are able to breed in almost any type of water-filled container (even with eutrophic water) as has been shown recently in Cuba (Diéguez et al., 2015; 2016). It is reasonable to say that the sources of Aedes immature stages depend on the local habits of water and not on the material of the container as mentioned by Kittayapong \& Strickman (1993). In this case, A. aegypti showed an overall preponderance for some materials, particularly in favour of plastic type, although varies depending on studies (Abe et al., 2005; Vezzani \& Schweigmann, 2002; García, Micieli, Achinelly, \& Marti, 2002; Barja-Simon, Le Goff, Callata, Walter, \& Bremond, 2009; Devera, Devera, \& Velázquez, 2013). In contrast, in Venezuela, cement and ceramic containers overcome the rest of the materials (Castillo, Brown, Castillo, Caprazo, \& Sánchez, 2016; Traviezo-Valles et al., 2016). However, it is important to be careful in the interpretation as one material could constitute the most available breeding site and therefore this will not indicate a specific attraction for it (Abe et al., 2005). Less literature is available to compare $C$. quinquefasciatus and A. albopictus. The fact that some materials are less suitable for breeding could be explained by high temperature in the water of the vase, the overheating of the inner surface where eggs are laid as well as by release of toxic particles as apparently occur with some types of metallic materials (i.e. copper) (Romi et al., 2000; Vezzani \& Schweigmann, 2002). This could explain the low CI recorded in glass containers and other varied materials.

The CI values obtained from Jarabacoa cemetery is in line with other studies carried out in Argentina and Venezuela, in which levels of infestation in cemeteries varied widely between 0 to $50 \%$ (Vezzani et al., 2001; Vezzani \& Schweigmann, 2002; Abe et al., 2005; Devera et al., 2013). The container availability (density of containers per area) was moderately superior in our study with respect to those reported in Vezzani et al. (2001). Note that these authors used the CI as the positive containers/waterfilled containers which in this case resulted in our CI index even higher (40.3\%). CI seems to dependant on other factors such as the environment (landscape), seasonality (periods of time), exposure of sunlight (sunlight/shaded), cultural habits (commemorative dates) and different type of cemeteries (Natal et al., 1997; Vezzani et al., 2001; Vezzani \& Schweigmann, 2002; Vezzani \& Albicócco, 2009; Devera et al., 2013). Therefore, the full understanding of the attraction of female mosquitoes to a specific material is the result of diverse factors that remain partly unknown due to the complexity of the variables involved.

Although no correlation was found between height and density levels in immature mosquitoes, greater densities of immature stages were found at ground level than at higher heights. Frequently, the burial system in cemeteries provides different levels that serve as wall niches for breeding. The vertical distribution of larvae and pupae of $A$. albopictus in a cemetery of Spain was not related to height 
from the ground: Similarly, Martins et al. (2010) did not found significant differences when compared different heights of breeding sites and noted the high capacity of Aedes spp. to colonize variables heights.

For the control of container breeding sites, integration of multiple methods is desirable. Considering that disposable plastic containers are the most common material by far in the present cemetery and in other studies mentioned, a simple measure to reduce the density of artificial breeding sites would rely on their elimination. Replacing water by sand and/or draining water weekly to avoid breeding sites is also plausible although challenging as container by container treatment is time-consuming and requires permanent attention. Novel approaches such as adding water crystals to flowering vases impeding the piling water, treat vases with a special material that turns water into a gel preventing mosquito development, keeping flowers fresh or even banning the use of natural flowers as occur in some cemeteries in Cuba, should also be considered.

Since permanent cement vases (i.e. graves or stationary jars) are the second most abundant container, other alternative measures are required, for example, the application of copper or larvicide-based control techniques. Adequate application of electric wire in flower pots with A. albopictus resulted very promising in reducing the immature stages in cemeteries of Europe (Romi et al., 2000; Eritja \& Herreros, 2017). The use of the larvicide temephos in an environment with high availability of potential breeding sites was effective in reducing $A$. aegypti populations in a cemetery of Argentina (Vezzani et al., 2004). Spinosad, is also an effective larvicide against $A$. aegypti and $A$. albopictus in semi-rural cemeteries of Mexico. The efficacy of Bti (Bacillus thuringiensis var. israelensis) seems to perform poorly when comparing with the latter ones (Marina et al., 2011; 2012). Pyriproxyfen larvicide application has demonstrated to be very effective to control urban mosquitoes in Brazil. The dust-particles in simple dissemination stations are transferred by female mosquitoes (mosquito-driven dissemination) to artificial breeding sites (Abad-Franch et al., 2015). This approach is promising for A. aegypti, $A$. albopictus or Culex spp. at small spatial scales, an scenario compatible with cemeteries. Other alternatives as biological control with nematodes, green algae or cyclopoid copepods resulted little effective to control mosquito immatures in cemeteries (Natal et al., 1997; Pons, Sans, Gomez, \& Calliari, 2008).

Using these appropriate control agents delivered by local authorities on the entrances of cemeteries sounds reasonable although for its success, public health education is essential to create knowledge and awareness of the residents on mosquito-borne diseases. We believe that in low-income countries of the Caribbean region, simple, cheap and easy implementation techniques may have better chances to be successful than novel and more sophisticated techniques such as those involving transgenic or Wolbachia-infected mosquitoes (Araújo, Carvalho, Loshino, Costa-da-Silva, \& Capurro, 2015). However, these techniques will prosper in a long-term perspective and will overcome the cost of reapplication and availability of qualified staff.

Unfortunately, in large-scale cemeteries, hand application of control agents would be impracticable (Vezzani, 2007). When the previous efforts fail or under the risk of potential epidemics, residual chemical control is the most efficient strategy available. Insecticides (adulticides) are commonly used as standard or routine practices from modified-cars provided by the Ministry of Health in the Caribbean islands. However, the particular lay-out of most cemeteries would obstruct conducting these duties by motorised-cars. Again, is highlighted that the solution usually is an integration of several techniques simultaneously or paralleled. This scenario becomes even more complicated when considering the existence of clandestine cemeteries or without appropriate staff maintenance, leading to densely vegetated areas and disposable/rubbish potential containers which favoured a continuous proliferation of mosquitoes (Barja-Simon, Le Goff, Callata, 
Walter, \& Bremond, 2009). At this point, it is worth noting that inadequate disposal of garbage (solid waste) not only produces a strong environmental deterioration but also contributes to the proliferation of $A$. aegypti and A. albopictus as noted Borge de Prada et al. (2018) in the Dominican Republic.

In conclusion, it is important to emphasize to Dominican authorities that control of mosquito vector, environmental management and health education programmes would be unsuccessful unless public support for these measures are secured (Abe et al., 2005). The arrival of invasive species and their spread to urban environment seem unstoppable and thus, integration of new methods should be taken into consideration. In an attempt to reduce potential breeding sites for immature stages in cemeteries, this study suggests the importance of a community-based physical activity intervention, in which both local authorities (gardeners and cemetery keepers) and visitors get involved in the removal or treatment of disposable water-filled containers. Finally, this study also contributes to targeting mosquito breeding sites for vector control efforts highlighting environmental variables as strategic points to be considered by public health authorities to implement control strategies.

Ethical statement: authors declare that they all agree with this publication and made significant contributions; that there is no conflict of interest of any kind; and that we followed all pertinent ethical and legal procedures and requirements. A signed document has been filed in the journal archives.

\section{ACKNOWLEDGMENTS}

This work is part of the project: "Sistema integrado de educación y vigilancia entomológica para la prevención y el control de enfermedades vehiculizadas por mosquitos (Diptera: Culicidae) en dos polos turísticos de República Dominicana" supported by the Fondo Nacional de Innovación y Desarrollo Científico y Tecnológico (FONDOCyT), Ministerio de Educación
Superior, Ciencia y Tecnología (MESCyT), Project No. 2015-112-145. The authors would like to thank Rancho Baiguate for its official involvement and unconditional support to the members of this research team. We are indebted to the personnel of the cemetery for allowing us to manipulate the flower containers and work freely in the collection of samples.

\section{RESUMEN}

Variables microambientales asociadas a mosquitos (Diptera: Culicidae) que habitan en recipientes en un cementerio urbano de República Dominicana. Los mosquitos (Diptera: Culicidae) son importantes vectores de diversos organismos patógenos, tales como arbovirus y protozoos. Los estadios inmaduros de los mosquitos pueden encontrarse en un amplio abanico de hábitats, tanto de origen natural como humano. Algunos lugares antrópicos, como los cementerios, sirven como prósperos hábitats artificiales para el desarrollo del ciclo de vida de los mosquitos. A pesar de constituir importantes focos para especies de interés vectorial, los cementerios urbanos son frecuentemente olvidados en los programas de vigilancia y control. Este estudio evaluó la asociación de algunas variables ecológicas (tipo de material, presencia de flores, disponibilidad de agua, y altura respecto al suelo) de los lugares de cría (recipientes) con los niveles de infestación de las fases preimarginales de los culícidos. En 2017, un cementerio urbano en Jarabacoa (República Dominicana) fue inspeccionado durante dos periodos climáticos (es decir: marzo: estación seca y agosto: estación húmeda) para: caracterizar los lugares de cría artificiales, captura de los estadios inmaduros de culícidos e identificación de los adultos emergidos a partir de las fases inmaduras. En total, 968 recipientes fueron examinados, conteniendo 7758 inmaduros en 203 (21.0\%) recipientes con agua pertenecientes a cuatro especies, Culex quinquefasciatus (50.5\%), Aedes aegypti (47.1\%), Aedes albopictus (1.9\%) y Culex nigripalpus (0.4\%). El índice de recipiente (IR) fue del $20.9 \%$, y los recipientes fabricados a partir de roca (cemento, cerámica y barro) y plástico tuvieron el mayor IR $=25.9$ y $23.4 \%$, respectivamente. Casi un $95 \%$ de los recipientes con agua infectados estaban constituidos de materiales tipo plástico o roca. No se encontró asociación entre el tipo de material del recipiente y la densidad. En general, mayor densidad de estadios inmaduros fue observada a nivel del suelo que a alturas mayores. Se observó un incremento significativo del número de $C$. quinquefasciatus en recipientes con flores y grandes volúmenes de agua. Por el contrario, los estadios de $A$. aegypti fueron más frecuentes en recipientes sin flores. Como reflejo de su comportamiento oportunista y amplia plasticidad ecológica, los mosquitos Culex y Aedes fueron abundantes en los cementerios, siendo capaces de desarrollar su ciclo de vida acuático en cualquier 
tipo de recipiente, con independencia del material que lo constituya. Nuestro estudio, por tanto, mostró que algunas variables ecológicas tienen un impacto crítico sobre el desarrollo de los estadios inmaduros de algunas especies de mosquitos. Tanto las autoridades de salud pública como los cuidadores del cementerio pueden beneficiare de estos resultados centrándose en la implementación de planes detallados y estrategias integradoras para el control y prevención de mosquitos que infectan cementerios.

Palabras clave: Aedes; Culex; cementerio; recipientes artificiales; variables ambientales; República Dominicana.

\section{REFERENCES}

Abad-Franch, F., Zamora-Perea, E., Ferraz, G., PadillaTorres, S., D., \& Luz, S., L. (2015). Mosquitodisseminated pyriproxyfen yields high breeding-site coverage and boosts juvenile mosquito mortality at the neighborhood scale. PloS Neglected and Tropical Diseases, 9(4), e0003702.

Abe, M., McCall, P. J., Lenhart, A., Villegas, E., \& Kroeger, A. (2005). The Buen Pastor cemetery in Trujillo, Venezuela: measuring dengue vector output from a public area. Tropical and Medicine International Health, 10, 597-603.

Addiss, D., \& Chuke, S. (2002). Lymphatic Filariasis in the Americas: An Epidemiologic History. Centers for Disease Control and Prevention, Report.

Alarcón-Elbal, P. M., Paulino-Ramírez, R., DiéguezFernández, L., Fimia-Duarte, R., Guerrero, K. A., \& González, M. (2017). Arbovirosis transmitidas por mosquitos (Diptera: Culicidae) en la República Dominicana: una revisión. The Biologist (Lima), 15(1), 193-219.

Araújo, H. R. C., Carvalho, D. O., Loshino, R. S., Costada-Silva, A. L., \& Capurro, M. L. (2015). Aedes aegypti control strategies in Brazil: incorporation of new technologies to overcome the persistence of dengue epidemics. Insects, 6(4), 576-594.

Barja-Simon, Z., Le Goff, G., Callata, R., Walter, A., \& Bremond, P. (2009). Infestación del Cementerio Santa Cruz de la Sierra por los mosquitos del vector Dengue. Bolivia. Revista de Enfermedades Infecciosas y Tropicales, 1(1), 29-32.

Barrera, R., Machado-Alison, C. E., \& Bulla, L. A. (1979). Criaderos, densidad larval y segregación de nicho en tres culicidae urbanos (Culex fatigans Wied., C. corniger Theo. y Aedes aegypti L.) en el cementerio de Caracas. Acta Cientifica Venezolana, 30, 418-424.

Barrera, R., Machado-Allison, C. E., \& Bulla, L. A. (1982). Mosquitoes and mourning in the Caracas cemetery. Antenna, 6, 250-252.
Bonizzoni, M., Gasperi, G., Chen, X., \& James, A. A. (2013). The invasive mosquito species Aedes albopictus: current knowledge and future perspectives. Trends of Parasitology, 29, 460-468.

Borge de Prada, M., Rodríguez-Sosa, M. A., VásquezBautista, Y. E., Guerrero K., A., \& Alarcón-Elbal, P. M. (2018). Mosquitos (Diptera, Culicidae) de importancia médica asociados a residuos sólidos urbanos en Jarabacoa, República Dominicana. Revista Salud Jalisco, Edición especial, 20-27.

Castillo, C., Brown, E., Castillo, L., Caprazo, M., \& Sánchez, L. (2016). Importancia de los floreros como criaderos de Aedes aegypti en tres cementerios del Estado Trujillo. Academia, 15, 35.

Day, J. F., Curtis, G. A., \& Edman, J. D. (1990). Rainfalldirected oviposition behavior of Culex nigripalpus (Diptera: Culicidae) and its influence on St. Louis encephalitis virus transmission in Indian River County, Florida. Journal of Medical Entomology, 27, 43-50.

De Figueiredo, M. L., Gomes, A. D., Amarilla, A. A., Leandro, A. D., Orrico, A. D., de Araujo, R. F.,... Figueiredo, L. T. M. (2010). Mosquitoes infected with dengue viruses in Brazil. Virology Journal, 27, 152.

Devera, R., Devera, Z., \& Velázquez, V. (2013). Presencia de Aedes aegypti en el cementerio de Jobo Liso de Ciudad Bolívar, estado Bolívar, Venezuela. Saber, 25(4), 358-364.

Diéguez, L., Pino, R., Andrés, J., Hernández, A., AlarcónElbal, P. M., \& San Martín, J. L. (2016). Actualización de los hábitats larvarios de Aedes aegypti (Diptera: Culicidae) en Camagüey, Cuba. Revista de Biología Tropical, 64(4), 1487-1493.

Diéguez, L., Pino Bacardi, R., Andrés García, J., Hernández Mojena, A., San Martín Martínez, J. L., \& Alarcón-Elbal, P. M. (2015). Bioecología de un mosquito invasor, Aedes (Stegomyia) albopictus (Diptera: Culicidae), en Camagüey, Cuba. Boletín de la Sociedad Entomológica Aragonesa (S.E.A.), 56, 251-256.

Eritja, R., \& Herreros, E. (2017). Spatial distribution of immature stages of Aedes albopictus (Skuse) (Diptera: Culicidae) in flower pots in a Spanish cemetery and field evaluation of metallic copper as a control agent. Journal of European Mosquito Control Association, 35, 13-17.

Farraudière, L., Sonor, F., Crico, S., Étienne, M., Mousson, L., Hamel, R.,.... Yébakima, A. (2017). First detection of dengue and chikungunya viruses in natural populations of Aedes aegypti in Martinique during the 2013-2015 concomitant outbreak. Revista Panamericana de Salud Pública, 41, e63.

Ferraguti, M., Martinez-de la Puente, M. J., Roiz, D., Ruiz, S., Soriguer, R., \& Figuerola, J. (2016). Effects of landscape anthropization on mosquito community 
composition and abundance. Scientific Reports, 6 , 29002.

Freitas, A. R. R., Alarcón-Elbal, P. M., Paulino-Ramírez, R., \& Donalisio, M. R. (2018). Excess mortality profile during the Asian genotype chikungunya epidemic in the Dominican Republic, 2014. Transactions of the Royal Society of Tropical Medicine and Hygiene, in press. DOI: 10.1093/trstmh/try072

Freitas, A., R. R., Alarcón-Elbal, P. M., \& Donalisio, M. R. (2018). Excess mortality in Guadeloupe and Martinique, islands of the French West Indies, during the chikungunya epidemic of 2014. Epidemiology and Infection, in press. DOI: 10.1017/ S0950268818002315

García, J. J., Micieli, M. V., Achinelly, M. F., \& Marti, G. A. (2002). Establecimiento de una población de Aedes aegypti L. en La Plata, Argentina. In O. D. Salomón (Ed.), Actualizaciones en Artropodología Sanitaria Argentina (pp. 149-153). Buenos Aires: Argentina: Fundación Mundo Sano.

Getachew, D., Tekie, H., Gebre-Michael, T., Balkew, M., \& Mesfin, A. (2015). Breeding sites of Aedes aegypti: Potential dengue vectors in Dire Dawa, East Ethiopia. Interdisciplinary Perspectives on Infectious Diseases, 1, 706276

Gonçalves, E. F. B. (1989). Incidência das espécies de mosquitos (Diptera: Culicidae) nas adjacências e cemitérios da cidade de São Paulo, Brasil. São Paulo, Brasil: UNAERP.

González Broche, R. (2006). Culícidos de Cuba. La Habana, Cuba: Editorial Científico Técnica.

Ibáñez-Bernal, S., Briseño, B., Mutebi, J. P., Argot, E., Rodríguez, G., Martínez-Campos, C., .... Flisser, A. (1997). First record in America of Aedes albopictus naturally infected with dengue virus during the 1995 outbreak at Reynosa, Mexico. Medical and Veterinary Entomology, 11, 305-309.

IBM Corporation. (2016). IBM SPSS Statistics for Windows. SPSS. Chicago, USA.

Kittayapong, P., \& Strickman, D. (1993). Distribution of container-inhabiting Aedes larvae (Diptera: Culicidae) at a dengue focus in Thailand. Journal of Medical Entomology, 30, 601-606.

Leisnham, P. T., LaDeau, S. L., \& Juliano, S. A. (2014). Spatial and Temporal Habitat Segregation of Mosquitoes in Urban Florida. Plos One, 9(3), e91655.

Marina, C. F., Bond, J. G., Casas, M., Muñoz, J., Orozco, A.,...Williams, T. (2011). Spinosad as an effective larvicide for control of Aedes albopictus and Aedes aegypti, vectors of dengue in southern Mexico. Pest Management Science, 67, 114-121.
Marina, C. F., Bond, J. G., Muñoz, J., Valle, J., Chirino, N., \& Williams, T. (2012). Spinosad: a biorational mosquito larvicide for use in car tires in southern Mexico. Parasites \& Vectors, 5, 95.

Martins, V. E., Alencar, C. H., Facó, P. E., Dutra, R. F., Alves, C. R.,... Guedes, M. I. (2010). Distribuição espacial e características dos criadouros de Aedes albopictus e Aedes aegypti em Fortaleza, Estado do Ceará. Revista da Sociedade Brasileira de Medicina Tropical, 43(1), 73-77.

Medlock, J. M., Hansford, K. M., Schaffner, F., Versteirt, V., Hendrickx, G., Zeller, H., \& Van Bortel, W. (2012). A review of the invasive mosquitoes in Europe: ecology, public health risks, and control options. Vector-borne and Zoonotic Diseases, 12, 435-447.

Mendéz, W., Liria, J., Navarro, J. C., Garcia, C. Z., Freier, J. E., Salas, R.,... Barrera, R. (2001). Spatial dispersion of adult mosquitoes (Diptera: Culicidae) in a sylvatic focus of Venezuelan Equine Encephalites Virus. Journal of Medical Entomology, 38, 813-821.

Natal, D., Gonçalves, E. F. B., \& Taveira, L. A. (1997). Proliferação de mosquitos (Diptera, Culicidae) em cemitérios e perspectivas de controle. Informe Epidemiológico do SUS, 6, 103-110.

Pons, M., Sans, K., Gomez, M., \& Calliari, D. (2008). Evaluation of Culex pipiens larvae control by cyclopoid copepods in an urban cemetery of Montevideo, Uruguay. Journal of Vector Ecology, 33, 212-215.

Rey, J. R., \& Lounibos, P. (2015). Ecología de Aedes aegypti y Aedes albopictus en América y transmisión de enfermedades. Biomédica, 35(2), 177-185.

Rodríguez-Sosa, M. A., Vásquez-Bautista, Y. E., FimiaDuarte, R., Guerrero, K. A., \& Alarcón-Elbal, P. M. (2018). Primer registro de Uranotaenia cooki (Diptera: Culicidae) para República Dominicana. Revista Colombiana de Entomología, 44(1), 141-144.

Romi, R., Di Luca, M., Raineri, W., Pesce, M., Rey, A., Giovannangeli, S.,... Bella, A. (2000). Laboratory and field evaluation of metallic Copper on Aedes albopictus (Diptera: Culicidae) larval development. Journal of Medical Entomology, 37(2), 281-285.

Rueda, J., Rodríguez-Sosa, M. A., Vásquez-Bautista, Y. E., Guerrero, K. A., \& Alarcón-Elbal, P. M. (2018). Primera cita de Culex (Culex) garciai González Broche, 2000 (Diptera: Culicidae) para La Española. Anales de Biología, 40, 95-101.

Service, M. (2012). Culicine mosquitoes (Culicinae). In R. Gaugler (Ed.), Medical Entomology Student, $5^{\text {th }}$ Ed. (pp. 54-84). Cambridge, UK: Cambridge University Press.

Shultz, G. W. (1989). Cemetery vase breeding of dengue vectors in Manila, Republic of the Philippines. 
Journal of European Mosquito Control Association, 5(4), 508-513.

Shultz, G. W. (1993). Seasonal abundance of dengue vectors in Manila, Republic of the Philippines. Southeast Asian Journal of Tropical Medicine and Public Health, 24(2), 369-375.

Subra, R. (1981). Biology and control of Culex pipiens quinquefasciatus Say, 1823 (Diptera, Culicidae) with special reference to Africa. Insect Science and its Application, 1(4), 319-338.

Traviezo-Valles, L. E., Cárdenas, E., Rodríguez, R., Jaspe, G., Jaspe, M.,... Morantes, L. (2014). Presencia de Aedes aegypti, transmisor del dengue, en el Cementerio de Sanare, estado Lara, Venezuela. Revista de Médico-Científica "Luz y Vida”, 5(1), 7-11.

Trout Fryxell, R. T., Freyman, K., Ulloa, A., Hendricks, B., Paulsen, D., Odoi, A., \& Moncayo, A. (2015). Cemeteries are effective sites for monitoring La Crosse virus ( $\mathrm{LACv}$ ) and these environments may play a role in LACv infection. Plos One, 10, e0122895.

Turell, M. J., Dohm, D. J, Sardelis, M. R., O’ Guinn, M. L., Andreadis, T. C., \& Blow, J. A. (2005). An update on the potential of North American mosquitoes (Diptera: Culicidae) to transmit West Nile Virus. Journal of Medical Entomology, 42, 57-62.

Vazeille, M., Moutailler, S., Coudrier, D., Rousseaux, C., Khun, H., Huerre, M.,... Failloux, A. B. (2007). Two chikungunya isolates from the outbreak of La Reunion (Indian Ocean) exhibit different patterns of infection in the mosquito, Aedes albopictus. Plos One, 2, e1168.

Vezzani, D., Velázquez, S. M., Soto, S., \& Schweigman, N. (2001). Environmental characteristics of the cemeteries of Buenos Aires City (Argentina) and infestation levels of Aedes aegypti (Diptera: Culicidae). Memórias do Instituto Oswaldo Cruz, 96, 467-471.

Vezzani, D., \& Schweigmann, N. (2002). Suitability of containers from different sources as breeding sites of Aedes aegypti (L.) in a cemetery of Buenos Aires city, Argentina. Memórias do Instituto Oswaldo Cruz, 97, 789-792.

Vezzani, D., Velásquez, S. M., \& Schweigmann, N. (2004). Controle de Aedes aegypti com temephos em cemitério de Buenos Aires, Argentina. Revista de Saúde Pública, 38(5), 738-740.

Vezzani, D. (2007). Review: Artificial container-breeding mosquitoes and cemeteries: a perfect match. Tropical Medicine \& International Health, 12(2), 299-313.

Vezzani, D., \& Albicócco, A. P. (2009). The effect of shade on the container index and pupal productivity of the mosquitoes Aedes aegypti and Culex pipiens breeding in artificial containers. Medical and Veterinary Entomology, 23, 78-84.

Webb, C. E. (2008). Mosquito ecology: field sampling methods "Mosquito ecology: field sampling methods." Australian Journal of Entomology, 47(4), 382-383. 